\title{
Importance of bioturbation and feeding by the polychaete Capitella sp. I in the degradation of di(2-ethylhexyl)phthalate (DEHP)
}

\author{
Rikke Hansen $^{1, *}$, Thomas L. Forbes ${ }^{1, * *}$, Peter Westermann ${ }^{2}$ \\ ${ }^{1}$ Department of Marine Ecology \& Microbiology, National Environmental Research Institute, PO Box 358, \\ Frederiksborgvej 399, DK-4000 Roskilde, Denmark
}

${ }^{2}$ Department of General Microbiology, University of Copenhagen, Sølvgade 83H, DK-1307 Copenhagen K, Denmark

\begin{abstract}
A microcosm study of the effect of Capitella sp. I (Polychaeta) population density on the mineralization of a pulse addition of the plasticizer DEHP (di[2-ethylhexyl]phthalate) demonstrated a 2 -fold increase in mineralization (cumulative ${ }^{14} \mathrm{CO}_{2}$ production) when worms were present. An additional experiment investigated the fate of ingested particle-bound ${ }^{14} \mathrm{C}$-DEHP and measured the loss of ingested ${ }^{14} \mathrm{C}$-DEHP into ${ }^{14} \mathrm{CO}_{2}, \mathrm{DO}^{14} \mathrm{C}$ and $\mathrm{PO}^{14} \mathrm{C}$ pools. Less than $1 \%$ of ${ }^{14} \mathrm{C}$ consumed during a $1 \mathrm{~h}$ ingestion period was ultimately respired as ${ }^{14} \mathrm{CO}_{2}$, while $10 \%$ was excreted as $\mathrm{DO}^{14} \mathrm{C}$ and $89 \%$ as $\mathrm{PO}^{14} \mathrm{C}$. Approximately $1 \%$ of ingested ${ }^{14} \mathrm{C}$ was retained in worm tissue $20 \mathrm{~h}$ after ingestion. Assuming density-independent feeding rates, worm respiration could account for $4.5 \%$ to $19.1 \%$ of the total microcosm ${ }^{14} \mathrm{CO}_{2}$ production, suggesting that microbial respiration to ${ }^{14} \mathrm{CO}_{2}$ was the dominant process. Pre-exposure of worms to DEHP $\left(10 \mu \mathrm{g} \mathrm{g}^{-1}\right.$ sediment dry wt) for 1 wk had no effect on the fate of ingested DEHP and distribution into the respective pools. Worms exerted a strong effect on ultimate DEHP degradation $\left({ }^{14} \mathrm{CO}_{2}\right.$ production) but the effect was manifest at the lowest worm density and did not increase with increasing population size. The lack of an increased effect at greater population densities may be due to population density-dependent factors acting to decrease such important parameters as individual worm ventilation and feeding rates. A density-dependent decrease in feeding rate is supported by the observation that measured ${ }^{14} \mathrm{C}$ body burdens were highest at lowest worm densities.
\end{abstract}

KEY WORDS: Bioturbation - Capitella sp. I · Phthalate esters - Sediment - Microbial degradation · Metabolism

\section{INTRODUCTION}

Infauna play an important role in the fate of organic matter and organic pollutants associated with organic matter (Gardner et al. 1979, Kristensen \& Blackburn 1987, Bauer et al. 1988, Kristensen et al. 1992, Aller 1994, Holmer et al. 1996). Improved understanding of the degradation of organic pollutants in sediments requires knowledge of the mechanisms of interaction between deposit-feeding invertebrates and sediment-associated microorganisms that is mediated by

\footnotetext{
- Present address: Darling Marine Center, University of Maine, Walpole, Maine 04573, USA

•-Addressee for correspondence.E-mail: tf@dmu.dk
}

bioturbation. Bioturbation is known to influence biogeochemical as well as physical processes in sediments (Rhoads 1974, Kristensen 1988, Boudreau 1998). Enhanced microbial degradation of organic pollutants is a typical effect of particle mixing and irrigation due to deposit-feeders (Gardner et al. 1979, Lee et al. 1982, Bauer et al. 1988, Holmer et al. 1996, Madsen et al. 1997). However, very few degradation studies have investigated the relative importance of deposit-feeders ability to accumulate and metabolize organic pollutants or to either stimulate or decrease microbial degradation rates (McElroy et al. 1990, Kure \& Forbes 1997).

The phthalate ester DEHP (di[2-ethylhexyl]phthalate) is a plasticizer primarily used in the production of 
soft polyvinylchloride. It is not chemically bound to the polymeric matrix and it therefore tends to be released from plastics, providing a potential risk to the aquatic environment entering via point sources and deposition from combustion processes. DEHP constitutes more than $50 \%$ of the global phthalate ester production annually (WHO 1992). The majority of phthalate esters released into the marine environment are rapidly adsorbed to the organic fraction of sediments and disperse in association with small particles (<ca $100 \mathrm{\mu m}$ ) due to their hydrophobic character (Al-Omran \& Preston 1987. Williams et al. 1995). The compound is weakly estrogenic (Jobling et al. 1995) and acute toxicity to aquatic organisms is low, which has been attributed to the limited water solubility of DEHP (Adams et al. 1995). However, bioavailability may be relatively higher for deposit-feeders who ingest large quantities of contaminated sediment, provided that the particlebound fraction is bioavailable. Furthermore, if the deposit-feeders possess a detoxification system, one risks underestimating bioavailability due to low bioaccumulation, thus overlooking potential sublethal effects. DEHP is microbially degradable under both aerobic and anaerobic conditions, suggesting that animal-driven phenomena such as irrigation/ventilation may be especially important (Nozawa \& Maruyama 1988, Gibbons \& Alexander 1989)

The deposit-feeding polychaete Capitella sp. I has been described as an enrichment opportunist, and it is often a dominant inhabitant in organic-rich marine sediments extensively contaminated with organic pollutants (Grassle \& Grassle 1974, Gray 1981). It is one of the most opportunistic sibling species with regard to reproductive mode and generation time (Grassle \& Grassle 1976). Previous mixing studies using particle tracers have shown that Capitella sp. I create 'conveyor-belt'-like profiles (Holmer et al. 1996, Madsen et al. 1997. Forbes et al. 1998, Forbes in press).

The species complex Capitella spp. (formerly known as Capitella capitata) can have a significant impact on the degradation of organic pollutants. Previous work has shown that the presence of Capitella spp. increased the degradation rate of 4 different polycyclic aromatic hydrocarbons (Gardner et al. 1979, Bauer et al. 1988, Madsen et al. 1997). Bauer et al. (1988) measured an increase in microbial activity in their microcosm study, leading them to suggest that the presence of Capitella spp. stimulates microbial degradation. Capitella spp. also appears able to metabolize organic contaminants. Lee \& Singer (1980) reported MFO (mixed function oxidase)-activity in Capitella spp. which converted polycyclic aromatic hydrocarbons (Kuwait crude oil) into water soluble metabolites. Radiotracer studies on individual worms (Capitella sp. I) pre-exposed to fluoranthene-contaminated sediment have also revealed that pre-exposed worms excreted substantially more dissolved carbon ingested as fluoranthene than worms which were not pre-exposed, suggesting an inducible metabolic system (Forbes et al. 1996).

This study addressed the following questions. (1) Does the presence of worms affect degradation of DEHP? (2) Does ingestion of contaminated sediment by worms affect degradation of DEHP? (3) Do worms influence the microbes involved in the degradation of DEHP? (4) Is biomixing by Capitella sp. I diffusive, and if so, can it be adequately described using the biodiffusion coefficient $D_{\mathrm{b}}$ ? Thus, mineralization of ${ }^{14} \mathrm{C}$ labelled DEHP in a microcosm experiment with Capitella sp. I was divided into mineralization due to stimulated microbial mineralization and mineralization by the worms. In order to separate ${ }^{14} \mathrm{CO}_{2}$ release due to stimulation of the sediment-associated microorganisms from that caused by the worms, the fate of ingested ${ }^{14} \mathrm{C}$-DEHP was investigated in a separate experiment. As MFO-activity has not been established for this particular Capitella sibling species, the effect of pre-exposure of worms on their mineralization ability was also investigated. Furthermore, the effect of different worm densities and the relationship between particle mixing and microbial ${ }^{14} \mathrm{C}$-DEHP mineralization was investigated in the microcosm experiment.

\section{MATERIALS AND METHODS}

Microcosm experiment. Microcosms used in this study were cylindrical glass containers $(18 \mathrm{~cm}$ high, $12 \mathrm{~cm}$ in diameter). The air supply passed through a sealed, gas-tight polyacrylic lid and left through $2 \mathrm{CO}_{2}$ traps connected in series. The air flow was maintained at a rate of $55 \mathrm{ml} \mathrm{min}^{-1}$, resulting in $97 \% \mathrm{O}_{2}$ saturation (tested by Winkler method). All microcosms were kept in the dark in a waterbath at $15^{\circ} \mathrm{C}$ during the experiment. The sediment was surface sediment collected in October 1995 in Isefjorden, Denmark. It was sieved $(<250 \mu \mathrm{m})$ and frozen $\left(-20^{\circ} \mathrm{C}\right)$ until use. The sediment contained $3.6 \%( \pm 0.56)$ carbon (dry wt after removal of carbonates by acid fuming, Hedges \& Stern 1984). Nitrogen content was $0.4 \%( \pm 0.07)$ dry wt (Perkin Elmer CHN-analyser, model 240C). Sediment background DEHP-concentration was $61 \mu \mathrm{g} \mathrm{kg}^{-1}$ sediment dry wt (gas chromatography-mass spectrometry, GC/MS).

Capitella sp. I (identified to sibling species by J. P. Grassle, Rutgers Univ., New Jersey, USA) was cultured in sediment procured from Isefjorden in a $50 \mathrm{l}$ aquarium containing $0.2 \mu \mathrm{m} \mathrm{FSW}$ (seawater) $\left(26 \%, 15^{\circ} \mathrm{C}\right.$ ). The worms were fed once a week with a mixture of sediment and fishfood (Tetramin ${ }^{\mathrm{r}}$ ) and overlying water was changed every 2 wk. 
The following 4 worm densities were used in the microcosm incubations: $0,3500,7000$ and 15000 worms $\mathrm{m}^{-2}$, densities equivalent to $0,40,80$ or 169 worms microcosm $\mathrm{m}^{-1}$. Triplicate microcosms were used for each treatment. One killed control microcosm was set up using a $30 \% \mathrm{w} / \mathrm{v} \mathrm{NaCl}$ solution as poison (Brock 1979). Each microcosm consisted of a bottom layer of $2 \mathrm{~cm}$ of preashed sand $(<1 \mathrm{~mm})$ followed by $6 \mathrm{~cm}$ of sediment and $6 \mathrm{~cm}(500 \mathrm{ml})$ of $0.2 \mu \mathrm{m}$ FSW $(26 \%$, $15^{\circ} \mathrm{C}$ ). Sediment and water were added to the microcosms and air flow was started $7 \mathrm{~d}$ prior to the addition of labelled sediment and worms. During the $22 \mathrm{~d}$ experiment, $90 \%$ of the overlying water in the microcosms was changed every second day.

Sediment labelling: $1.85 \mathrm{MBq}{ }^{14} \mathrm{C}$-DEHP (UL-ring, specific activity: $392 \mathrm{MBq} \mathrm{mmol}{ }^{-1}$. Sigma) was dissolved in $2 \mathrm{ml}$ of acetone and added to $411 \mathrm{~g}$ moist sediment slurry (particle size $<63 \mu \mathrm{m}$ ). In addition, $3.7 \mathrm{MBq}{ }^{51} \mathrm{CrCl}_{3}$ (Dupont No. NEZ020, chromic chloride in $0.5 \mathrm{M} \mathrm{HCl}$, specific activity: $13.8 \mathrm{MBq} \mathrm{mg}^{-1}$ ) was first added to $2 \mathrm{ml} 0.5 \mathrm{M} \mathrm{HCl}+2 \mathrm{ml} 0.5 \mathrm{M} \mathrm{NaOH}$ and then added to the sediment slurry. The slurry was kept in the dark on a reciprocating table for $24 \mathrm{~h}$. During contamination of the microcosms the overlying water was lowered to a height of $2 \mathrm{~cm}$ and $31.6 \mathrm{~g}{ }^{14} \mathrm{C} /{ }^{51} \mathrm{Cr}$ labelled sediment slurry was carefully distributed as a $2 \mathrm{~mm}$ layer on the top of the sediment surface in each of the 13 microcosms.

${ }^{14} \mathrm{CO}_{2}$ in the gas phase: The $\mathrm{CO}_{2}$ traps were $20 \mathrm{ml}$ glass scintillation vials with $15 \mathrm{ml} 0.5 \mathrm{M} \mathrm{NaOH}$ acting as a $\mathrm{CO}_{2}$ absorber. Trapping efficiency at a flow rate of $55 \mathrm{ml} \mathrm{min}^{-1}$ was $98 \%$ (tested with ${ }^{14} \mathrm{C}-\mathrm{NaHCO}_{3}$ ). The $\mathrm{CO}_{2}$-traps were changed and radioactivity was measured every second day by adding $10 \mathrm{ml}$ of Instagel (Packard Inc.) to a subsample of $5 \mathrm{ml} \mathrm{CO}_{2}$-absorber. All ${ }^{14} \mathrm{C}$ samples were kept in the dark for $24 \mathrm{~h}$ and then counted on a Liquid Scintillation Counter (Beckman LS 1801) and corrected for background and quench.

${ }^{14} \mathrm{CO}_{2}, \mathrm{DO}^{14} \mathrm{C}$ and $\mathrm{PO}^{14} \mathrm{C}$ in overlying water: The overlying water was exchanged every second day with $0.2 \mu \mathrm{m}$ FSW. At each exchange a $5 \mathrm{ml}$ sample was acidified with $0.5 \mathrm{ml} 0.5 \mathrm{M} \mathrm{HCl}$ and flushed with $\mathrm{N}_{2}$ for 10 min to drive off ${ }^{14} \mathrm{CO}_{2} \cdot{ }^{14} \mathrm{CO}_{2}$ was trapped in $5 \mathrm{ml} 0.5$ $\mathrm{M} \mathrm{NaOH}$ in a glass vial and $10 \mathrm{ml}$ Instagel was added to both the ${ }^{14} \mathrm{CO}_{2}$ sample and the acidified water sample. This procedure was performed to distinguish between inorganic ${ }^{14} \mathrm{C}$ and $\mathrm{DO}^{14} \mathrm{C} / \mathrm{PO}^{14} \mathrm{C} .{ }^{14} \mathrm{CO}_{2}$ activ ity in the overlying water was added to ${ }^{14} \mathrm{CO}_{2}$ measured in the gas phase, giving an estimate which was assumed to equal total ${ }^{14} \mathrm{CO}_{2}$ release

PO ${ }^{14} \mathrm{C}$ and ${ }^{51} \mathrm{Cr}$ sediment profiles: Initial sediment cores (triplicates) were sampled from all microcosms just before worms were added and final core samples were taken $22 \mathrm{~d}$ after the addition of worms. The corers consisted of plastic cylinders of $1 \mathrm{~cm}$ in diameter with a plunger sealing the open end to create a partial vacuum during core removal. Cores were frozen and sectioned into $0.5 \mathrm{~cm}$ layers in the upper $1 \mathrm{~cm}$ and then into $1 \mathrm{~cm}$ layers down to $6 \mathrm{~cm}$. Porewater was extracted (see below) and, after having freeze-dried the sediment samples, known amounts of sediment were transferred to $5 \mathrm{ml}$ vials and ${ }^{51} \mathrm{Cr}$ activity determined (Packard Instruments, Cobra II). The samples were then transferred carefully to glass vials and $1 \mathrm{ml}$ Soluene (Packard Inc.) was added. After $24 \mathrm{~h}$ the samples were sonicated for $10 \mathrm{~min}$ and $10 \mathrm{ml}$ Ultima Gold LSC fluor (Packard Inc.) was added.

DO ${ }^{14} C$ in porewater: Triplicate sediment cores were sampled from all the microcosms, frozen and sectioned into $0.5 \mathrm{~cm}$ layers in the upper $1 \mathrm{~cm}$ and then into $1 \mathrm{~cm}$ layers down to $6 \mathrm{~cm}$. Porewater was first extracted by centrifugation $(3180 \times g, 15 \mathrm{~min})$ and pipetted off and then $\mathrm{DO}^{14} \mathrm{C}$ and $\mathrm{PO}^{14} \mathrm{C}$ were separated by centrifugation $\left(20000 \times g, 45 \mathrm{~min}\right.$ ). The $\mathrm{DO}^{14} \mathrm{C}$ fraction was acidified in order to remove ${ }^{14} \mathrm{CO}_{2}$, and $2 \mathrm{ml}$ Instagel was added to $1 \mathrm{ml}$ porewater.

Tissue analysis: 90 worms (10 per microcosm) were removed at the end of the experiment and were placed for $8 \mathrm{~h}$ in FSW to clear their guts. No fecal pellets were left in the worms after $8 \mathrm{~h}$. The tissues of the worms were analysed for ${ }^{51} \mathrm{Cr}$ - and ${ }^{14} \mathrm{C}$-activity using the same procedure as for sediment. Prior to tissue analysis worms were videotaped with a camera mounted on a dissecting microscope for later size determination by image analysis (JAVA Inc., Erkrath, Germany). Replicate $(\mathrm{n}=3)$ lengths $(L)$ and areas $(A)$ for each worm were then converted to body volume (bdvol $\left[\mathrm{mm}^{3}\right]=$ $\left(\pi A^{2} / 4 L\right)$

Gut-fate experiment. Sediment ${ }^{14} \mathrm{C}$-spiking: A $2 \mathrm{ml}$ homogenized sediment slurry (particle size < $63 \mu \mathrm{m}$ ) was labelled with $1.85 \mathrm{MBq}{ }^{14} \mathrm{C}$-DEHP dissolved in acetone and left in the dark on a reciprocating table for $24 \mathrm{~h}$. The slurry was then rinsed 5 times with FSW to remove unincorporated isotope (Lopez 1989). The sediment specific activity was $7.55 \times 10^{4} \mathrm{dpm}$ (disintegrations per minute) ${ }^{14} \mathrm{C} \mathrm{mg}^{-1}$ sed dry wt.

Worm pre-exposure to DEHP: Twenty-five worms were added to a $500 \mathrm{ml}$ glass beaker containing DEHPcontaminated sediment with a nominal concentration of $10 \mu \mathrm{g} \mathrm{g}^{-1}$ sed dry wt (pre-exposed group). This concentration corresponded to the maximum potential exposure of the worms in the microcosm experiment and was assessed as follows. At the beginning of the experiment when the worms were added to the microcosms, they burrowed through the upper $2 \mathrm{~mm}$ of the radiolabelled sediment layer. Initially, the surface layer had an activity of $8.95 \mathrm{kBq} \mathrm{g}^{-1}$ sed dry wt equal to $8.96 \mu \mathrm{g} \mathrm{DEHP} \mathrm{g}^{-1}$ sed dry wt. Assuming that bulk sediment ${ }^{14} \mathrm{C}$-activity is diluted during the experiment due to particle mixing, we decided to use $10 \mu \mathrm{g} \mathrm{DEHP} \mathrm{g}^{-1}$ 
sed dry wt as the maximum exposure concentration Another glass beaker was set up with 25 worms in cold sediment (control group). The glass beakers with worms were kept in the dark in a waterbath $\left(15^{\circ} \mathrm{C}\right)$ for $7 \mathrm{~d}$.

Experimental design: On Day 8,35 pll ${ }^{14} \mathrm{C}$-labelled sediment slurry and $10 \mathrm{ml}$ seawater were added to 24 glass vials $(20 \mathrm{ml})$. The body size of 12 worms from each group (pre-exposed and control groups) was measured before the worms were added to the vials After a 1 h ingestion period (ca 1 gut passage time, Forbes 1989) the worms were rinsed from sediment with seawater and transferred to new vials containing uncontaminated sediment and $10 \mathrm{ml} \mathrm{FSW}$. This procedure was used to avoid accumulation of ${ }^{14} \mathrm{C}$-DEHP due to multiple gut fillings. The experiment lasted $20 \mathrm{~h}$ and during that period the worms were transferred 3 times to uncontaminated sediment and FSW (after 1,5 and $20 \mathrm{~h}$ ). This procedure was performed to investigate excretion over time.

${ }^{14} \mathrm{CO}_{2}$ and $\mathrm{DO}^{14} \mathrm{C}$ in the overlying water: Three $\mathrm{ml}$ overlying water from each incubation vial was sampled to measure total dissolved ${ }^{14} \mathrm{C}\left(\mathrm{TD}^{14} \mathrm{C}\right)$. To separate ${ }^{14} \mathrm{CO}_{2}$ and $\mathrm{DO}^{14} \mathrm{C}$ an additional $3 \mathrm{ml}$ overlying water was transferred to vials with a $25 \mathrm{~mm}$ Whatman GF/C filter mounted on a hook attached to a sealing silicone lid. The filter was soaked with $30 \mu$ Soluene as a ${ }^{14} \mathrm{CO}_{2}$-absorber. Six drops of concentrated $\mathrm{H}_{3} \mathrm{PO}_{4}$ were added with a syringe through the lid and the vials were left on a reciprocating table for $5 \mathrm{~h}$. The filters and water samples were then transferred separately to new vials. To the filters $1 \mathrm{ml}$ Soluene and $10 \mathrm{ml}$ Instagel were added whereas $10 \mathrm{ml}$ Instagel was added to the water samples.

$P O^{14} \mathrm{C}$ activity: ${ }^{14} \mathrm{C}$ in fecal matter was collected on a GF/C filter and $1 \mathrm{ml}$ Soluene was added. After $24 \mathrm{~h}$ the samples were sonicated for $10 \mathrm{~min}$ and $10 \mathrm{ml}$ Ultima Gold was added and the samples were held an additional $24 \mathrm{~h}$ in darkness to minimize chemiluminescence. These procedures were repeated after each worm transfer. At the end of the experiment worms were rinsed in seawater and ${ }^{14} \mathrm{C}$-activity determined.

The effect of sediment-associated microorganisms on ${ }^{14} \mathrm{C}$-pool distribution: To examine whether sediment-associated microorganisms changed the ${ }^{14} \mathrm{C}$ pools during the period between transfers, 9 vials each with $35 \mu l{ }^{14} \mathrm{C}$-labelled sediment slurry, $10 \mathrm{ml}$ overlying water and 1 pre-exposed worm were incubated. At the $1 \mathrm{~h}$ transfer all worms were removed and 3 vials were analysed immediately, while the remaining vials were analysed after 5 and $20 \mathrm{~h}$ with 3 vials per period. Sediment and overlying water was analysed in the same manner as sediment and overlying water from the other transfer vials in the experiment.
Modelling and statistical methods. Microcosm experiment: The cumulative ${ }^{14} \mathrm{CO}_{2}$ release with time was tested by repeated measures ANOVA where the factors were density, time and their interaction. Pairwise differences in ${ }^{14} \mathrm{CO}_{2}$ release among densities were compared using Tukey's HSD test. Body size differences within microcosm replicates and among density treatments were compared by nested ANOVA. ${ }^{14} \mathrm{C}$ body burden as a function of worm density was analysed by ANCOVA with body size as the covariate.

Particle mixing in the microcosm treatments was estimated using a 1-dimensional transient-state biodiffusion model with bioturbation expressed independently as the parameter $D_{\mathrm{b}}$ (Berner 1980). Since the microcosms were pulsed only once at the beginning of the experiment with a $2 \mathrm{~mm}$ layer of labelled sediment, sedimentation can be ignored as a vertical mass transfer mechanism, giving:

$$
\frac{\partial A}{\partial t}=D_{b} \frac{\partial^{2} A}{\partial x^{2}}
$$

where $A$ is the ${ }^{51} \mathrm{Cr}$ tracer activity, $t$ is time, $x$ is depth, and $D_{\mathrm{b}}$ (units: length ${ }^{2}$ time $^{-1}$ ) is the biodiffusion coefficient. The decay term in the equation can be omitted because ${ }^{51} \mathrm{Cr}$ activity was corrected for decay prior to use in the biodiffusion model. ${ }^{51} \mathrm{Cr}$ activity within a given depth section was expressed as a fraction of the total ${ }^{51} \mathrm{Cr}$ activity in that profile. For a non steady-state system the model assumes that the tracer exists solely on the sediment surface at time zero $(A=0$ at $x>0$ and $A=1$ at $x=$ $0)$, and the sediment-water interface is reflective $(\delta A / \delta x$ $=0$ at $x=0$ ). The solution to Eq. (1) is (Crank 1975):

$$
A(x)=\frac{1}{\left(\pi D_{b} t\right)^{1 / 2}} \exp \left(-x^{2} / 4 D_{b} t\right)
$$

The best fit to the ${ }^{51} \mathrm{Cr}$ profiles was determined by nonlinear least squares curve fitting with $D_{\mathrm{b}}$ as the only free parameter. $D_{\mathrm{b}}$ was also estimated from the worm population data following Wheatcroft et al. (1990) using the equation where particle motion is a function of the distance a particle moves and the time spent between 2 steps:

$$
D_{\mathrm{b}}=L^{2} / 2 \Omega
$$

where $L$ is the distance of a particle step expressed as worm length and $\Omega$ is the mean particle rest period.

Gut-fate experiment: The amount of ${ }^{14} \mathrm{C}$-DEHP ingested in the 2 worm groups was analysed by ANCOVA with body size as covariate. In order to compare the pre-exposed and the control worms $\mathrm{DO}^{14} \mathrm{C}$ and $\mathrm{PO}^{14} \mathrm{C}$ release rates, the cumulative $\mathrm{DO}^{14} \mathrm{C}$ and $\mathrm{PO}^{14} \mathrm{C}$ release with time was described by fitting data to a first order-rate expression:

$$
A(t)=A_{A} \exp (1 /-k t)
$$



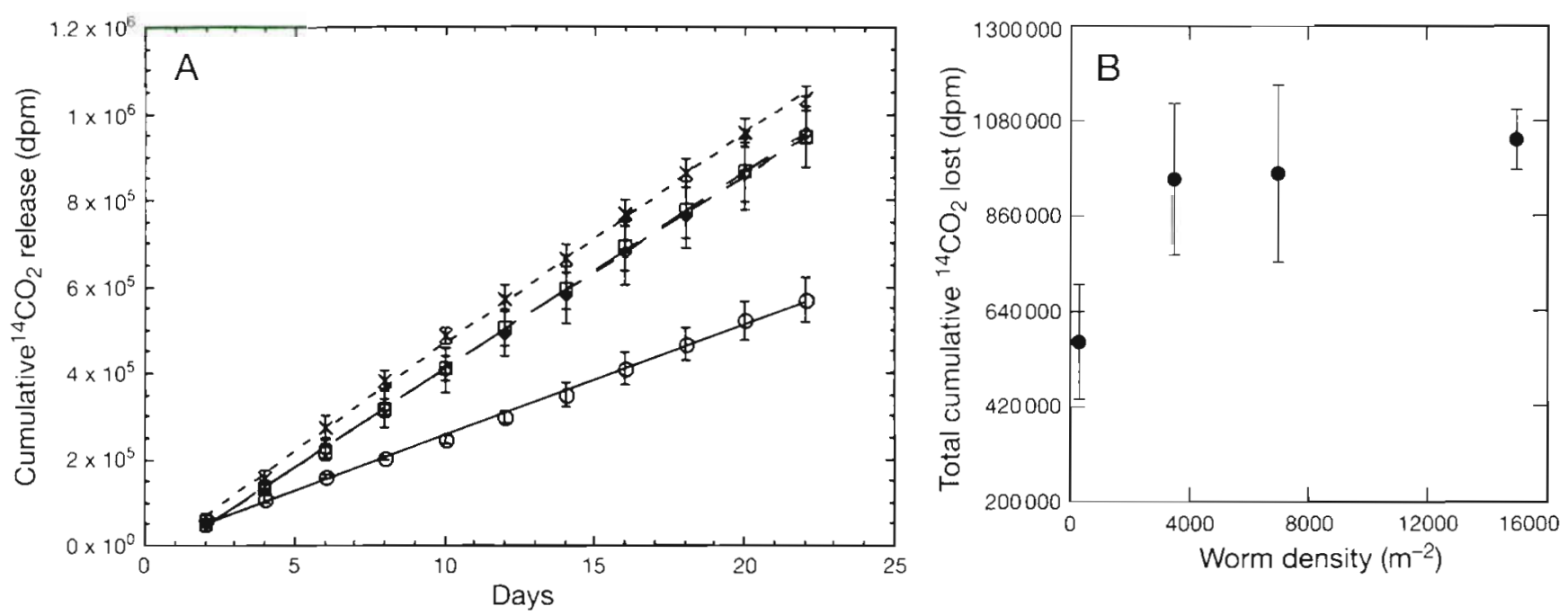

Fig. 1. Microcosm experiment (A) Cumulative ${ }^{14} \mathrm{CO}_{2}$ release versus time. (o) without worms $\left({ }^{14} \mathrm{CO}_{2}[\mathrm{dpm}]=25537 x+1992, \mathrm{r}^{2}=\right.$ 0.98); (口) 3500 worms m $\left.{ }^{-214} \mathrm{CO}_{2}(\mathrm{dpm})=45436 \mathrm{x}-44408, \mathrm{r}^{2}=0.98\right) ;(\diamond) 7000$ worms $\mathrm{m}^{-2}\left({ }^{14} \mathrm{CO}_{2}[\mathrm{dpm}]=45140 x-45014, \mathrm{I}^{2}=0.97\right)$ and $(x) 15000$ worms $\mathrm{m}^{-2}\left({ }^{14} \mathrm{CO}_{2}[\mathrm{dpm}]=49213 x-25944, \mathrm{r}^{2}=0.99\right)$. Data presented as mean of triplicates and 2 standard deviations. (B) Total cumulative ${ }^{14} \mathrm{CO}_{2}$ released as a function of worm density. Error bars are $95 \%$ confidence limits of the mean

Table 1 Single classification ANOVA for the effect of worm density on total ${ }^{14} \mathrm{CO}_{2}$ released during the microcosm experiment

\begin{tabular}{|lcccc|}
\hline Source of variation & df & SS & $F$ & p \\
\hline Worm density & 3 & $3.92 \times 10^{11}$ & 33.9 & 0.00007 \\
Error & 8 & $3.09 \times 10^{10}$ & & \\
\hline
\end{tabular}

where $A(t)$ is $\mathrm{DO}^{14} \mathrm{C}$ or $\mathrm{PO}^{14} \mathrm{C}$ activity (dpm) at time $t$, $A_{A}$ is the asymptotic total $\mathrm{DO}^{14} \mathrm{C}$ or $\mathrm{PO}^{14} \mathrm{C}$ activity and $k$ is a first-order rate constant describing release of ${ }^{14} \mathrm{C}$-DEHP expressed in units of time ${ }^{-1}$. Statistical analyses were performed with JMP® version 2.0.4 (SAS for the MacIntosh $\circledast$ )

\section{RESULTS}

\section{Microcosm experiment}

\section{Visual observations}

The worms began building tubes a few hours after they were added to the microcosms. Throughout the experiment they reworked the sediment actively leaving an accumulated layer of fecal pellets at the surface with numerous protruding tubes consisting of black fecal pellets. The microcosms without worms remained light brown in the upper 1 to $2 \mathrm{~mm}$ layer whereas the microcosms with worms had a surficial light brown layer of 25 to $30 \mathrm{~mm}$. Worms burrowing into the dark greyish sediment left a light brown coating around the burrow, creating a sediment with a patchy appearance. We avoided collecting females with eggs as we procured worms for the microcosms. However, at the end of the experiment a number of juvenile worms were observed, indicating that the worms reproduced during the experiment.

$$
{ }^{14} \mathrm{CO}_{2} \text { release }
$$

The cumulative ${ }^{14} \mathrm{CO}_{2}$ release was strongly influenced by worm density (Table 1, Fig. 1A,B). Comparison among worm densities indicated that the total ${ }^{14} \mathrm{CO}_{2}$ release from the control group was significantly lower than the 3 worm treatments (ANOVA, Table 1 , density effect: $p=0.00007$ ). Total ${ }^{14} \mathrm{CO}_{2}$ loss did not differ among the 3 worm treatments (Fig. 1B, Bonferroniadjusted post hoc tests, all $\mathrm{p}>0.60$ ). Total ${ }^{14} \mathrm{C}$ lost as ${ }^{14} \mathrm{CO}_{2}$ after $22 \mathrm{~d}$ was also expressed in percent of the total nominal amount of ${ }^{14} \mathrm{C}$-DEHP added to each microcosm. Results were $6.6 \%( \pm 0.7=\mathrm{SD} ; \mathrm{n}=3)$ without worms, $11.9 \%( \pm 0.9=\mathrm{SD} ; \mathrm{n}=3)$ at 3500 worms $\mathrm{m}^{-2}, 11.8 \%( \pm 1.1=\mathrm{SD} ; \mathrm{n}=3)$ at 7000 worms $\mathrm{m}^{-2}$ and $12.8 \%( \pm 0.2=\mathrm{SD} ; \mathrm{n}=3)$ at 15000 worms $\mathrm{m}^{-2}$. Thus there was no density dependence in the effect of worms on total ${ }^{14} \mathrm{CO}_{2}$ release rates

\section{${ }^{14} \mathrm{CO}_{2}$ release in killed control}

The ${ }^{14} \mathrm{CO}_{2}$ release in the killed control is an estimate of ${ }^{14} \mathrm{CO}_{2}$ release with time due to abiotic factors. Based 
on 1 microcosm, a linear fit showed a ${ }^{14} \mathrm{CO}_{2}$ release rate of about $379 \mathrm{dpm} \mathrm{d}^{-1}\left(\mathrm{r}^{2}=0.93, \mathrm{p}<0.001\right)$. Thus, less than $0.5 \%$ of the added ${ }^{14} \mathrm{C}$-DEHP was lost as ${ }^{14} \mathrm{CO}_{2}$ due to abiotic factors during the experimental period compared to $6.6 \%$ in the control.

\section{Sedimentary ${ }^{51} \mathrm{Cr}$ and ${ }^{14} \mathrm{C}$ profiles}

The ${ }^{51} \mathrm{Cr}$ profiles were fitted to the biodiffusion model (Eq. 2, see 'Materials and methods') (Fig. 2). Non linear fit $D_{\mathrm{b}}$ values for each worm treatment were $17.44( \pm 6.35=\mathrm{SE}) \mathrm{cm}^{2} \mathrm{yr}^{-1}$ for 3500 worms $\mathrm{m}^{-2}\left(\mathrm{r}^{2}=\right.$ $0.68), 13.94( \pm 5.24=\mathrm{SE}) \mathrm{cm}^{2} \mathrm{yr}^{-1}$ for 7000 worms $\mathrm{m}^{-2}$ $\left(\mathrm{r}^{2}=0.67\right)$ and $14.77( \pm 5.93=\mathrm{SE}) \mathrm{cm}^{2} \mathrm{yr}^{-1}$ for 15000 worms $\mathrm{m}^{-2}\left(\mathrm{r}^{2}=0.64\right)$, respectively. Mean $D_{\mathrm{b}}$ values did not differ significantly from each other (ANOVA, $\mathrm{p}=$ 0.350). Note that curve fits (Fig. 2) predict greater than observed penetration at intermediate depths (ca 0.5 to $3.0 \mathrm{~cm})$.

Calculation of $D_{\mathrm{b}}$ according to Wheatcroft et al. (1990) (Eq. 3, see 'Materials and methods') was performed in the following manner. Average worm length $(L)$ in the 3 worm density treatments was $10.42( \pm 1.00=$ $\mathrm{SD}) \mathrm{mm}$. In order to estimate mean particle rest period $(\Omega)$ we estimated time interval before reingestion of the same particle (assuming fecal pellet breakdown). The upper $3 \mathrm{~cm}$ sediment was considered the bioturbated zone and consisted of $573 \mathrm{~g}$ sed (wet wt), which was equal to $3.39 \times 10^{5} \mathrm{~mm}^{3}$ sed wet wt (density = $1.69 \mathrm{~g} \mathrm{~cm}^{-3}$ ). Given an average worm body size of $11.39 \mathrm{~mm}^{3}$, a gut turnover time of $17.5 \mathrm{guts}^{-1}$ (Forbes \& Lopez 1989), and 40 worms in the microcosm, approximately $7973 \mathrm{~mm}^{3}$ sed passed through the worms per day in the 3500 worms $\mathrm{m}^{-2}$ treatment. Dividing the total amount of sediment in the upper $3 \mathrm{~cm}$ layer $\left(3.39 \times 10^{5} \mathrm{~mm}^{3}\right.$ sed) by the amount of sediment processed per day by the worms $\left(7973 \mathrm{~mm}^{3}\right.$ sed $\mathrm{d}^{-1}$ ) yields an estimate of $\Omega$ of $43 \mathrm{~d} . \Omega$ for the other 2 worm densities were 21 and $10 \mathrm{~d}$ for 7000 and 15000 worms $\mathrm{m}^{-2}$, respectively. This gives $D_{\mathrm{b}}$ values of $4.66,9.32$ and $19.69 \mathrm{~cm}^{2} \mathrm{yr}^{-1}$ with increasing worm density. These $D_{\mathrm{b}}$ values were then plugged into the biodiffusion model and the fitted curves are shown in Fig. 2 (dotted lines). This approach yielded curves which were somewhat poorer fits to the data than those generated by nonlinear least squares methods. There was no significant relationship between ${ }^{14} \mathrm{CO}_{2}$

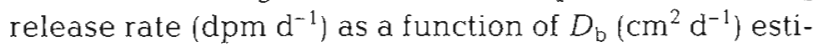
mated according to Wheatcroft et al. (1990) (Pearson correlation, graph not shown). This lack of correlation is in part due to the fact that the Wheatcroft estimates must increase with increasing population density and the observed release rates did not. In the presence of worms, both model-estimated (Crank 1975) $D_{\mathrm{b}}$ s and

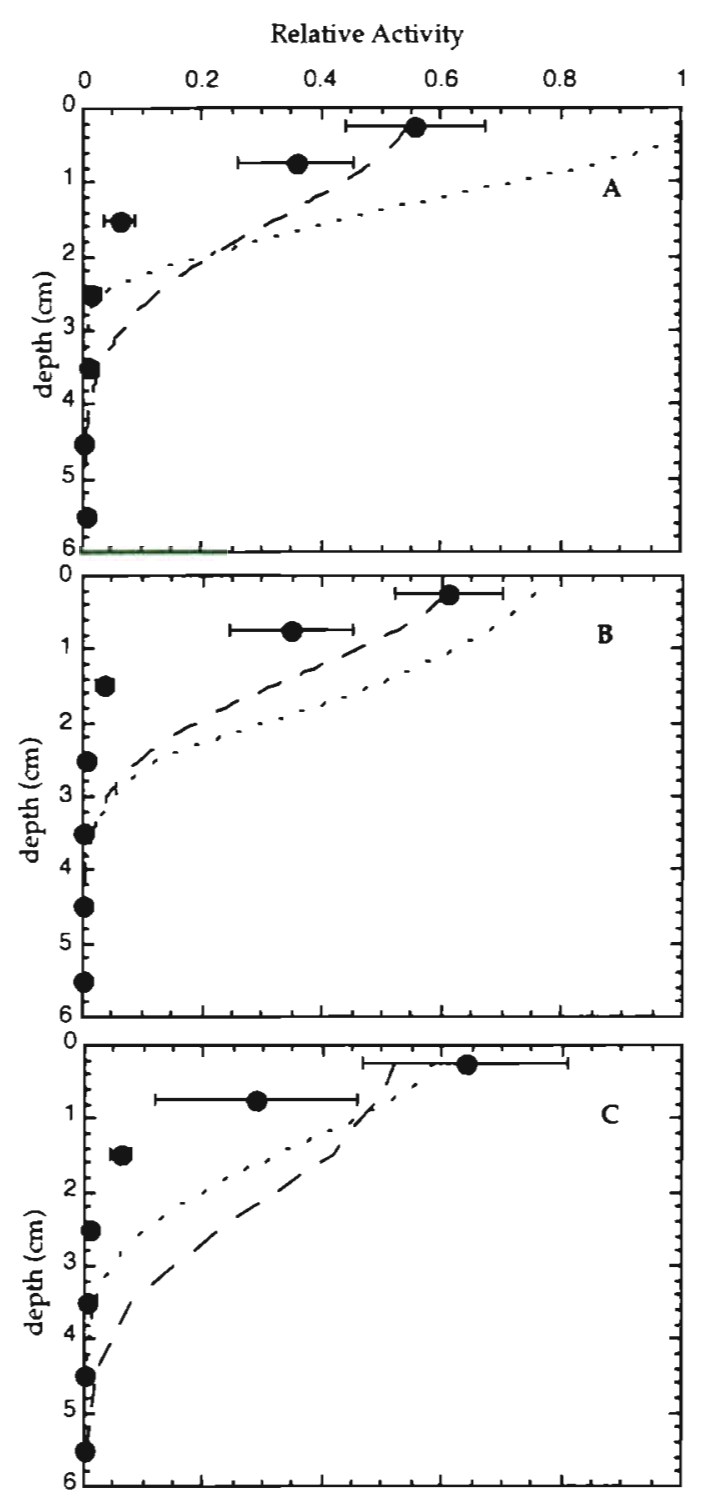

Fig. 2. Microcosm, experiment. Sedimentary ${ }^{51} \mathrm{Cr}$ profiles (A) for 3500, (B) 7000 and (C) 15000 worms $\mathrm{m}^{-2}$ at the end of the experiment. The profiles are fitted to the diffusion model, assuming non steady state $(---$ ) (Crank 1975). In addition, $D_{\mathrm{h}}$ was estimated according to wheatcroft et al. (1990) and subsequently used in the biodiffusion model (- . ). Data are presented as the mean and standard error of triplicate microcosms

total cumulative ${ }^{14} \mathrm{CO}_{2}$ loss rates were constant, and therefore independent of worm density.

The particle-bound ${ }^{14} \mathrm{C}$ profiles are shown in Fig. 3 together with the ${ }^{51} \mathrm{Cr}$ profiles. The ${ }^{14} \mathrm{C}$ and ${ }^{51} \mathrm{Cr}$ profiles did not differ from each other and about $90 \%$ of both radionuclides were found in the upper $2 \mathrm{~cm}$ sediment layer. Thus DEHP carbon was transported in a manner indistinguishable from that of the overall worm-driven particle transport. 


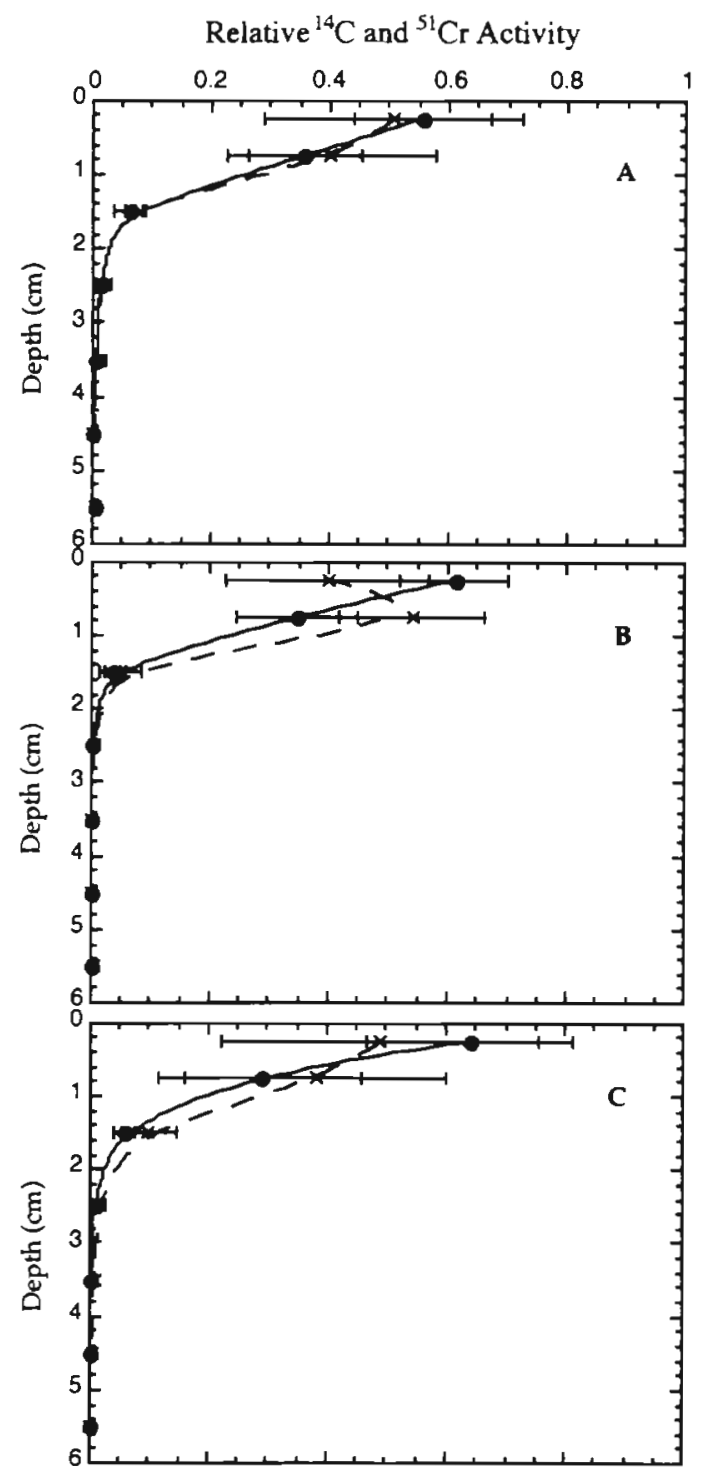

Fig. 3. Microcosm experiment. Particle-bound ${ }^{14} \mathrm{C}(x)$ and ${ }^{51} \mathrm{Cr}$ (-) profiles for (A) 3500, (B) 7000 and (C) 15000 worms $\mathrm{m}^{-2}$ at the end of the experiment

$\mathrm{DO}^{14} \mathrm{C}$ in porewater

$\mathrm{DO}^{14} \mathrm{C}$ concentrations in porewater with and without worms declined with sediment depth and could be fitted to an exponential expression (Fig. 4). The areas below the curves were estimated and $\mathrm{DO}^{14} \mathrm{C}$ activity in porewater without worms increased with time (Student's $t$-test, $\mathrm{p}<0.033$, df $=4$ ), whereas total $\mathrm{DO}^{14} \mathrm{C}$ present in the porewater with worms present did not change significantly with time, indicating that the worms prevented the buildup in porewater of dissolved DEHP or its metabolites (Student's $t$-test, 3500 worms $\mathrm{m}^{-2}: \mathrm{p}=0.382$, $\mathrm{df}=4 ; 7000$ worms $\mathrm{m}^{-2}, \mathrm{p}=$ $0.576, \mathrm{df}=4 ; 15000$ worms $\mathrm{m}^{-2}: \mathrm{p}=0.208$, df $=4$ ).
Table 2. Nested ANOVA on body volume as a function of worm density in the microcosm experiment

\begin{tabular}{|lrrrc|}
\hline Source of variation & df & SS & $F$ & p \\
\hline Among treatments & 2 & 34.13 & 0.359 & $>0.05$ \\
$\begin{array}{c}\text { Among microcosms } \\
\text { within treatments } \\
\text { Within subgroups (error) }\end{array}$ & 76 & 3045.29 & & \\
\hline
\end{tabular}

Worm ${ }^{14} \mathrm{C}$ body burden in the treatments

The body size of 10 worms from each microcosm did not differ within microcosm replicates and among density treatments (data not shown, ANOVA results in Table 2). Average worm ${ }^{14} \mathrm{C}$-body burden was $55( \pm 49)$, $31( \pm 29)$ and $27( \pm 21) \mathrm{dpm} \mathrm{mm}^{-3}$ bdvol for 3500,7000 and 15000 worms $\mathrm{m}^{-2}$, respectively. ${ }^{14} \mathrm{C}$-body burden differed among worm densities when corrected for body size (ANCOVA, analysis of covariance), indicating a decline in ${ }^{14} \mathrm{C}$-body burden with increasing worm density ( $p<0.001)$. It was not possible to detect any ${ }^{51} \mathrm{Cr}$ in worm tissue, confirming that the worms had emptied their guts of sediment during the $8 \mathrm{~h}$ defecation period.

\section{Gut-fate experiment}

\section{Body volumes of DEHP pre-exposed and control worms}

The body sizes of pre-exposed worms were smaller than those of control worms (pre-exposed: $4.74( \pm 1.28)$ $\mathrm{mm}^{3}$; control: $6.51( \pm 1.77) \mathrm{mm}^{3}$, Student's $t$-test, $p<$ 0.01 , df $=22$ ). Since body size was not measured before pre-exposure, it was not possible to determine whether worm growth rate had been affected by DEHP exposure although it is likely given that worms were not significantly different in size in the microcosms.

Relation between body size and ${ }^{34} \mathrm{C}$-DEHP ingested

The total amount of ${ }^{14} \mathrm{C}$-DEHP ingested during the $1 \mathrm{~h}$ feeding period did not differ between pre-exposed and control worms when corrected for body size (ANCOVA, $F_{0.05 \mid 1,21\}}=0.11, p=0.74$ ). On average, less than $1 \%$ of ingested ${ }^{14} \mathrm{C}$ was retained in worm tissue after $20 \mathrm{~h}$ (data not shown).

\section{Size-specific ${ }^{14} \mathrm{CO}_{2}$ release}

${ }^{14} \mathrm{CO}_{2}$ release due to Capitella sp. I's gut passage did not differ between pre-exposed and control worms 
(Student's $t$-test, $\mathrm{p}=0.493, \mathrm{df}=22$ ). On average 1.1 $( \pm 0.8) \mathrm{dpm} \mathrm{mm}-3 \mathrm{~h}^{-1}$ of ingested ${ }^{14} \mathrm{C}$ was lost as ${ }^{14} \mathrm{CO}_{2}$, which was equivalent to a total of $0.51 \%$ of ingested ${ }^{14} \mathrm{C}$ which we have assumed is due to worm respiration/metabolism.

It is possible to estimate the potential worm contribution to the total ${ }^{14} \mathrm{CO}_{2}$ release in the microcosm experiment by making the following assumptions. We first assumed that the labelled pulse of sediment in the microcosm experiment was evenly distributed in the bioturbated zone (max. $30 \mathrm{~mm}$ depth); this would result in an average sediment specific activity of $1.42 \times 10^{4}$ $\mathrm{dpm} \mathrm{g}^{-1}$ sed wet wt in the upper $30 \mathrm{~mm}$ layer. Given an average worm size of $11.4 \mathrm{~mm}^{3}$ and known feeding rate data, each worm can process approximately 17.5 gut volumes $\mathrm{d}^{-1}$ (Forbes 1989). Thus approximately 200 $\mathrm{mm}^{3}$ wet sediment should have passed through each worm in the form of fecal pellets each day. The low worm density treatment ( 3500 worms $\mathrm{m}^{-2}$ ) consisted of 40 worms inhabiting sediment with a bulk density of $1.69 \mathrm{~g} \mathrm{~cm}^{-3}$. Sediment thus passed through the 40 treatment worms at an overall rate of approximately $13.5 \mathrm{~g}$ $\mathrm{d}^{-1}$ (wet wt), ignoring any compaction due to the production of fecal pellets. This amount of sediment corresponds to $1.91 \times 10^{5} \mathrm{dpm} \mathrm{d}^{-1}$. Accounting for the loss rate of $0.51 \% \mathrm{~d}^{-i}$ calculated above for worm metabo-
Iism of DEHP, the ${ }^{14} \mathrm{CO}_{2}$ loss potentially due to worms is $974 \mathrm{dpm}$ or $4.51 \%$ of the total ${ }^{14} \mathrm{CO}_{2}$ release $\mathrm{d}^{-1}$ in the low density treatment. Similarly, ${ }^{14} \mathrm{CO}_{2}$ respired by the worms was $10.84 \%$ of the total ${ }^{14} \mathrm{CO}_{2}$ release $\mathrm{d}^{-1}$ in the 7000 and $19.07 \%$ in the 15000 worms $\mathrm{m}^{-2}$ treatment, respectively. Note that this calculation assumes no ingestion selectivity for organic matter/DEHP, an assumption which is likely violated for many organic contaminants (Forbes et al. 1998).

\section{$\mathrm{DO}^{14} \mathrm{C}$ release in overlying water}

The cumulative ${ }^{14} \mathrm{C}$ recovered as $\mathrm{DO}^{14} \mathrm{C}$ increased with time in both groups (Fig. 5) to $10 \%$ of total ${ }^{14} \mathrm{C}$ loss. Eq. (4) (see 'Materials and methods') was used to describe $D \mathrm{O}^{14} \mathrm{C}$ release of each worm and the mean $k$ values from each worm group were then compared (pre-exposed: $k_{\mathrm{p}, \mathrm{DOC}}=1.237[ \pm 0.485] \mathrm{h}^{-1}$; control: $\left.k_{\mathrm{C}, \mathrm{DOC}}=0.809[ \pm 0.223] \mathrm{h}^{-1}\right)$. The mean $k$ values differed significantly from each other (Student's $t$-test, $\mathrm{p}<$ 0.012 , df $=21$ ), indicating that pre-exposure to DEHP resulted in a relatively higher initial excretion of ${ }^{14} \mathrm{C}$ recovered as $\mathrm{DO}^{14} \mathrm{C}$. However, the total amount of excreted $\mathrm{DO}^{14} \mathrm{C}$ did not differ significantly between the 2 groups.

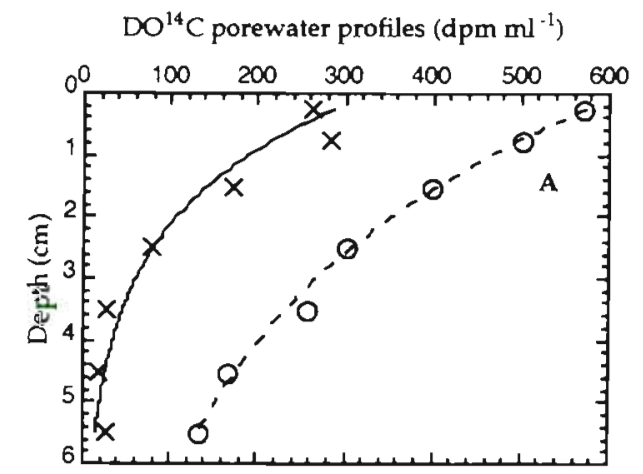

$\mathrm{DO}^{14} \mathrm{C}$ porewater profiles (dpm $\mathrm{ml}^{-1}$ )
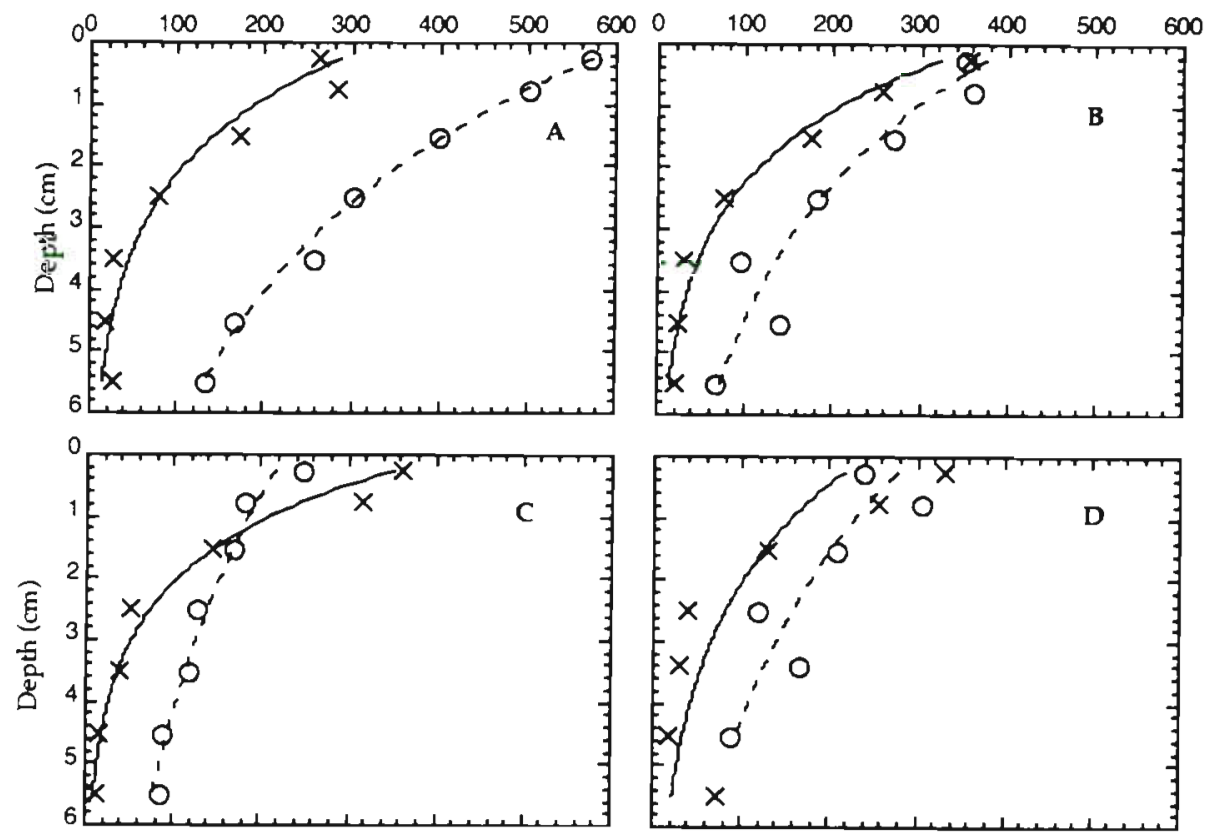

Fig. 4. Microcosm experiment. $D \mathrm{O}^{14} \mathrm{C}$ sediment profiles (A) without worms and (B-D) with worms $(\mathrm{B}=3500 ; \mathrm{C}=7000 ; \mathrm{D}=15000$ worms $\left.\mathrm{m}^{-2}\right)$ at the beginning $(t=0)(-)$ and at the end $(t=1)(---)$ of the experiment. The data are fitted to an exponential equation $\mathrm{DO}{ }^{14} \mathrm{C}(\mathrm{dpm})=a \exp (-k \times \operatorname{depth})(\mathrm{A}) t=0, \mathrm{r}^{2}=0.92 ; t=1, \mathrm{r}^{2}=0.99 ;(\mathrm{B}) t=0, \mathrm{r}^{2}=0.99 ; t=1, \mathrm{r}^{2}=0.93 ;(\mathrm{C}) t=0, \mathrm{r}^{2}=0.96 ; t=1$, $\mathrm{r}^{2}=0.92 ;$ (D) $t=0, \mathrm{r}^{2}=0.85 ; t=1, \mathrm{r}^{2}=0.71$ ). Each data point is based on triplicate samples 


$$
\mathrm{PO}^{14} \mathrm{C} \text { pool }
$$

Both worm groups had emptied most of their gut within 5 h. Approximately $89 \%$ of the ingested ${ }^{14} \mathrm{C}$ in both groups was recovered ultimately as feces and mucus (Fig. 6). The cumulative $\mathrm{PO}^{14} \mathrm{C}$ release for each worm was fitted to a first-order expression. The mean $k$ values (pre-exposed: $k_{\mathrm{p}, \mathrm{POC}}=2.628[ \pm 1.357] \mathrm{h}^{-1}$ control: $k_{c, p o c}=2.354[ \pm 0.851] \mathrm{h}^{-1}$ ) of the 2 worm groups did not differ (Student's t-test, $\mathrm{p}=0.565 \mathrm{df}=$ 21). Thus, pre-exposed worms did not excrete $\mathrm{PO}^{14} \mathrm{C}$ faster than the control worms, nor was the total amount of $\mathrm{PO}^{14} \mathrm{C}$ different.

\section{Sediment-associated microbial $\mathrm{DO}{ }^{14} \mathrm{C}$ release}

$\mathrm{DO}^{14} \mathrm{C} /{ }^{14} \mathrm{CO}_{2}$ and $\mathrm{PO}^{14} \mathrm{C}^{14} \mathrm{CO}_{2}$ ratios were analysed as a function of incubation time for the 9 vials from which all worms were removed at the $1 \mathrm{~h}$ transfer to check whether sediment-associated microorganisms mineralized $\mathrm{DO}^{14} \mathrm{C}$ or $\mathrm{PO}^{14} \mathrm{C}$ to ${ }^{14} \mathrm{CO}_{2}$ between transfer periods. Neither of the ratios changed as a function of incubation time (ANOVA, $\mathrm{p}=0.381$ for $\mathrm{DO}^{14} \mathrm{C}^{14} \mathrm{CO}_{2}$ $\mathrm{p}=0.302$ for $\mathrm{PO}^{14} \mathrm{C}^{14} \mathrm{CO}_{2}$ ). Thus, it was assumed that microorganisms did not change the distribution of ${ }^{14} \mathrm{C}$ pools.

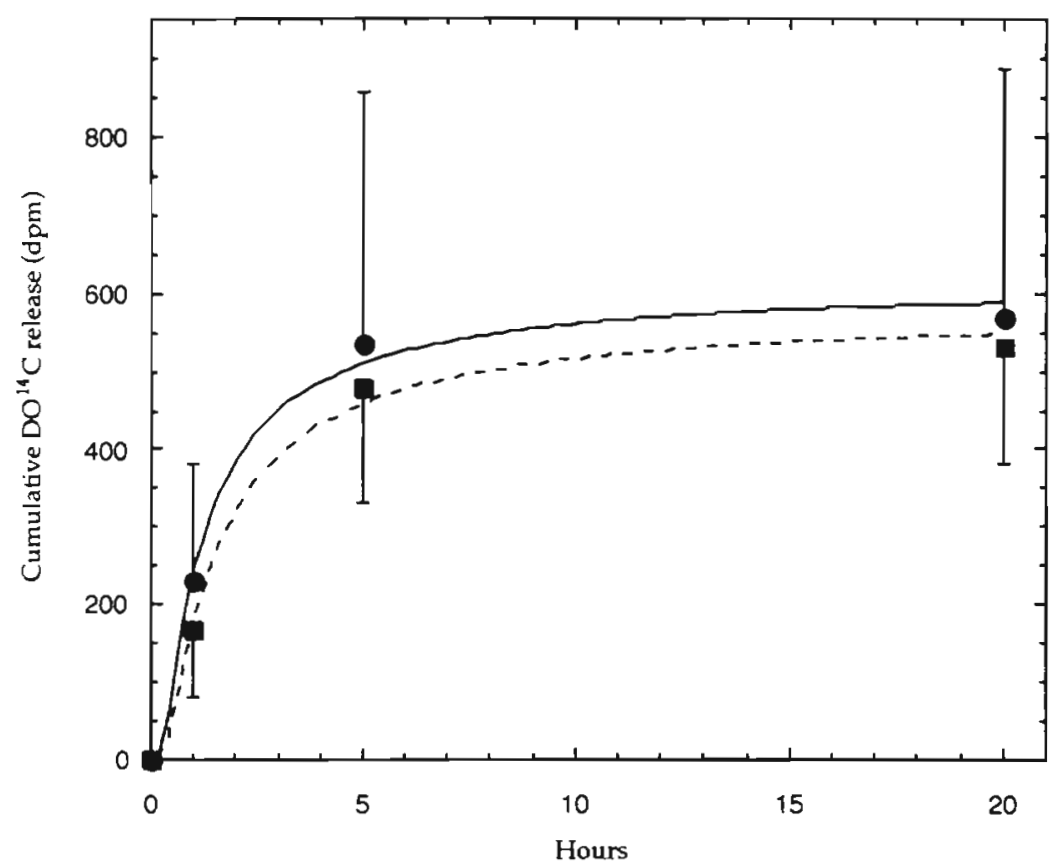

Fig. 5. Gut-fate experiment. Ingested particle-bound ${ }^{14} \mathrm{C}$ lost as $\mathrm{DO}^{14} \mathrm{C}$ during $20 \mathrm{~h}$ fitted to a first order-rate expression. Data are presented as the cunulative mean and standard deviation of 11 and 10 worms in the pre-exposed ($\left(k_{\mathrm{p}, \mathrm{DOC}}=1.237 \pm 0.485 \mathrm{~h}^{-1}\right)$ and control groups $(--)\left(k_{\mathrm{c}, \mathrm{DOC}}=0.809 \pm 0.223 \mathrm{~h}^{-1}\right)$ respectively. The uncertainty is calculated by error propagation (Skoog et al. 1992)

\section{DISCUSSION}

Our results suggest that the main mechanism responsible for the increase in ${ }^{14} \mathrm{CO}_{2}$ release in the presence of Capitella sp. I is bioturbation, which stimulates sediment-associated microorganisms. Mineralization of ingested DEHP by worms was evident but less important. Nevertheless, calculations suggest that worm metabolism of DEHP may account for up to $19 \%$ of the total ${ }^{14} \mathrm{CO}_{2}$ release in the high worm density microcosms. However, the worms in microcosms probably ingested smaller amounts of the ${ }^{14} \mathrm{C}$-labelled compound than we assumed because they were feeding at depth while ${ }^{14} \mathrm{C}$-DEHP was added at the surface. In addition, a density-dependent decrease in worm feeding rates may also have occurred, further diminishing the relative importance of worm metabolism. The low rate of ${ }^{14} \mathrm{CO}_{2}$ release of ingested ${ }^{14} \mathrm{C}$-labelled particulate bound compounds in sediment is similar to results presented by Forbes et al. (1996) where Capitella sp. I respired less than $1 \%$ of ingested ${ }^{14} \mathrm{C}$-fluoranthene. However, Capitella spp. densities in organic-rich sediments heavily contaminated with organic pollutants can often reach densities greater than 100000 worms $\mathrm{m}^{-2}$ in enriched environments (Grassle \& Grassle 1974). Under such conditions even low rates of mineralization in the gut may contribute relatively more to the total degradation of particle bound compounds than shown in our experiment unless density-dependent mechanisms such as decreases in feeding or irrigation rates have strong negative effects on the degradation rate.

The amount of a compound respired directly by Capitella sp. I most likely depends on the quantity taken up by the worms and their metabolic capacity for degradation as well as a compound's bioavailability. In general, polychaetes possess a pronounced variation in metabolic abilities. For example, Nereis diversicolor and $N$. virens metabolize benzo[a]pyrene much more effectively than Capitella sp. I (Driscoll \& McElroy 1996, Hansen $\&$ Forbes unpubl. data). The inherently large variability in animal abundance makes it important to understand the metabolic capabilities of the dominant organisms in a community when assessing the relative importance of benthic organisms and sediment-associated microorganisms.

Among the various factors affecting bioavailability, food quality may be 


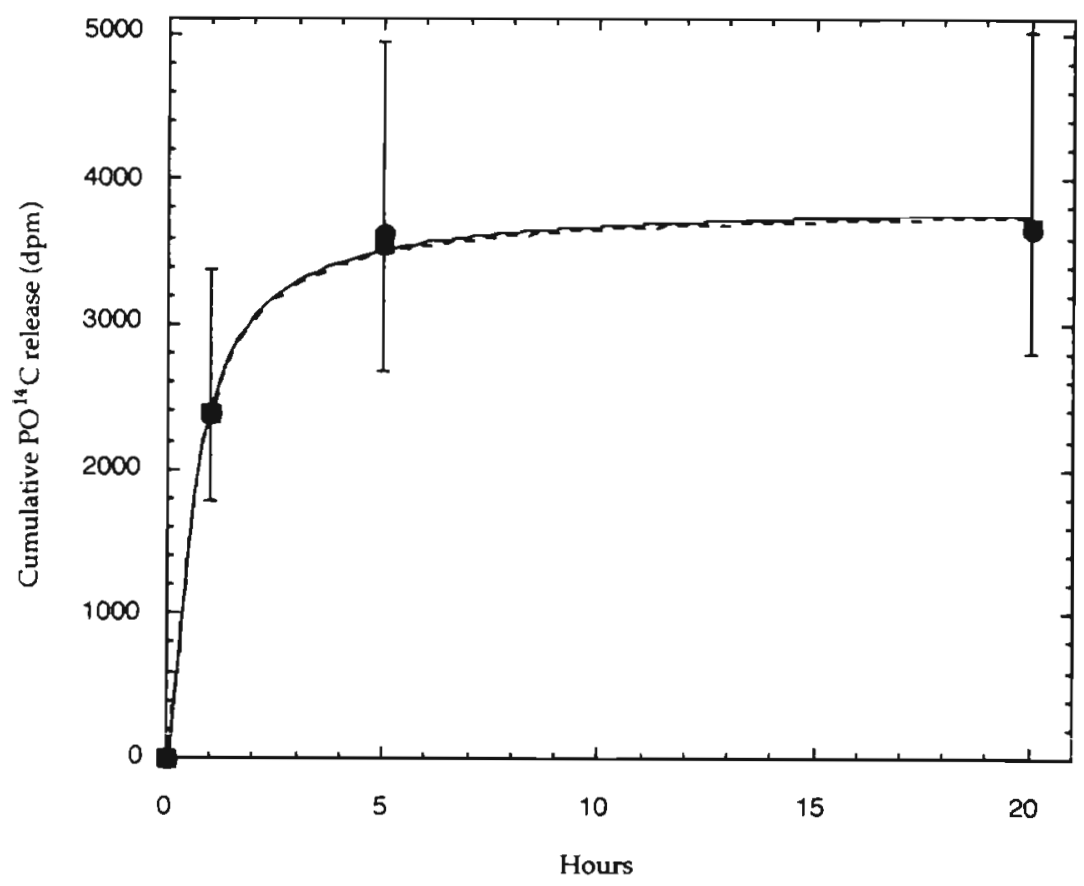

Fig. 6. Gut-fate experiment. Ingested ${ }^{14} \mathrm{C}$ lost as $\mathrm{PO}^{14} \mathrm{C}$ during $20 \mathrm{~h}$ was fitted to a first order-rate expression. Data are presented as the cumulative mean and standard deviation of 11 and 10 worms in the pre-exposed $(-)\left(k_{\mathrm{p}, \text { POC }}=2.628\right.$ $\left.\pm 1.357 \mathrm{~h}^{-1}\right)$ and control groups $(--)\left(k_{\mathrm{c}, \mathrm{POC}}=2.354 \pm 0.851 \mathrm{~h}^{-1}\right)$ respectively. The uncertainty is calculated by normal error propagation of standard deviations (Skoog et al. 1992)

significant. Studies on absorption efficiency of cadmium with varying quality food sources have shown that Capitella sp. I absorbs relatively more cadmium when the metal is associated with high quality food (Selck et al. in press). The degree to which there is a positive relation between absorption across the gut epithelium and the quality/lability of ingested sediment to which an organic pollutant is sorbed is presently unclear.

The sediment ${ }^{51} \mathrm{Cr}$ profiles were relatively poor fits to a simple biodiffusion model and yielded $D_{\mathrm{b}}$ values which did not vary as a function of worm density. One of the assumptions of biodiffusion models states that particle mixing is random throughout the bioturbated zone. This assumption is likely not true for isolated Capitella sp. I populations in microcosms and probably contributed to lack of fit. Madsen et al. (1997) showed that fluoranthene bound to relatively organic-poor glass beads was mixed in an advective 'conveyor-belt' fashion, leaving the contaminated beads in a relatively intact layer. In contrast, comparatively nutritious natural sediment was mixed in a much more diffusive manner, leading to a more uniform distribution with depth. The conveyor belt profile may be due to the fact that worms rejected less nutritious glass beads when feeding. Thus the interaction of a particles' food value and the toxicity of the bound contaminant(s) are likely to be very significant factors controlling the extent and mode of biomixing.

If $D_{\mathrm{b}}$ is in fact constant over a range of worm densities, this suggests that worm density may act as a feed-back mechanism on particle mixing processes. For example, feeding rate may be inversely related to worm density. One potential mechanism may involve increasing pelletization of the sediment and consequent increases in foraging time as ingestible grains are located among the pellets. This leads to the prediction that, for a given population density, increasing rate of labile organic matter input and hence food supply would ailow greater feeding and bioturbation rates, provided the aerobic oxidative capacity of the sediment is not exceeded. Increased feeding activity as a function of high quality organic matter input makes sense from a purely physiological perspective as well (e.g. Cammen 1989, Taghon 1989). These factors may contribute as underlying mechanisms to the relationship between labile organic matter input and the global mean depth of the bioturbated zone (e.g. Boudreau 1998).

$D_{b}$ estimated according to Wheatcroft et al. (1990) and used in the biodiffusion model also resulted in very similar curve fits. If it is assumed that ${ }^{14} \mathrm{C}$-DEHP is homogenously mixed into the upper $30 \mathrm{~mm}$ during $22 \mathrm{~d}$, then a better fit results despite the fact that about $90 \%$ of the radionuclide was found in the upper $20 \mathrm{~mm}$ sediment. For example, changing maximum mixing depth to $20 \mathrm{~mm}$ yields $D_{b}$ values of $6.97,13.98$ and $29.51 \mathrm{~cm}^{2} \mathrm{yr}^{-1}$ respectively. Determination of mixing depth and the assumption of homogenous mixing becomes particularly critical when working with depositfeeders who may ingest and defecate sediment nonrandomly with depth. Another uncertainty with regard to the calculation of $D_{\mathrm{b}}$ comes with the assumption of a gut turnover rate of $17.5 \mathrm{~d}^{-1}$, which may have been too low, and that $L$ may not express particle motion in a proper way if particle transport is actually oriented in a particular direction. This is further complicated if feeding rate and behaviour change with worm density. Wheatcroft et al. (1990) predict a strong relationship between $D_{b}$ and the population density, a relationship which we did not see in our experiment, perhaps due to density-dependent decreases in worm feeding rates. The differences between the 2 approaches used to esti- 
mate $D_{\mathrm{b}}$ diminished with increasing worm density, but none of the $D_{b}$ values resulted in curves which fit the observed profiles particularly well when calculated for a single species population and both approaches predicted somewhat greater mixing than we actually observed at intermediate depths (Fig. 2).

There was no significant relation between $D_{\mathrm{b}}$ values determined by either method and ${ }^{14} \mathrm{CO}_{2}$ release rates in the microcosms. This is due to the fact that, after an initial increase between the control and lowest worm density, release rates were independent of animal density.

Pre-exposure to DEHP-contaminated sediment in the gut-fate experiment resulted in a higher initial $\mathrm{DO}^{14} \mathrm{C}$ release rate, although the total amount of $\mathrm{DO}^{14} \mathrm{C}$ ultimately released did not differ between treatments. We did not examine whether $\mathrm{DO}^{14} \mathrm{C}$ was more bioavailable to microbial mineralization than the parent compound. In this context, it is essential to determine the composition of the $\mathrm{DO}^{14} \mathrm{C}$ pool to fully understand interactions between deposit-feeders and microorganisms during the degradation of ${ }^{14} \mathrm{C}$-DEHP. The $\mathrm{DO}^{14} \mathrm{C}$ pool may consist of solubilized parent compound due to digestive fluids in the gut environment with surfactant properties (Mayer et al. 1996) or due to ${ }^{14} \mathrm{C}$-DEHP desorbed from sediment particles. Alternatively, gut-associated microorganisms may excrete products that increase the solubility of ${ }^{14} \mathrm{C}$ DEHP, a phenomena which has been observed with sewage-sludge-associated bacteria (Gibbons \& Alexander 1989). Forbes et al. (1996) showed that fluoranthene metabolites (non specified $\mathrm{DO}^{14} \mathrm{C}$ pool) released by Capitella sp. I were not available to microbial attack during an incubation of up to $19 \mathrm{~h}$. This result may be explained by the fact that the incubation time was too short for the microorganisms to mineralize possible metabolic products or parent compounds-indicating a relatively non-labile release product.

The porewater $\mathrm{DO}^{14} \mathrm{C}$ profiles in the microcosms without worms showed accumulation of $\mathrm{DO}^{14} \mathrm{C}$ at the end of the experiment, suggesting that the microorganisms transformed ${ }^{14} \mathrm{C}$-DEHP into polar metabolites under both aerobic and anaerobic conditions or that the solubility of ${ }^{14} \mathrm{C}$-DEHP increased. Alternatively, $\mathrm{DOC}$ increases could be due to the buildup of microbial metabolites that were not released by irrigation. Based on the low background DEHP sediment concentration, we assumed that sediment-associated microorganisms were not adapted to DEHP degradation prior to analysis. Although there was no significant difference in $\mathrm{DO}^{14} \mathrm{C}$ activity in the overlying water as a function of worm density (data not shown), the trend in our data strongly suggests that overlying $\mathrm{DO}^{14} \mathrm{C}$ in microcosms with worms was higher than in the microcosms without worms. This observation is consistent with the fact that $D O^{14} \mathrm{C}$ content in the porewater profiles did not differ significantly when worms were present. Thus, irrigation activity may act to decrease additionally potential interactions between deposit-feeders and sediment-associated microorganisms with regard to the fate of $\mathrm{DO}^{14} \mathrm{C}$ by increasing the loss of $\mathrm{DO}^{14} \mathrm{C}$ from porewater.

Apparently Capitella sp. I was able to metabolize and excrete ${ }^{14} \mathrm{C}$-DEHP to a degree that less than $1 \%$ of the ingested ${ }^{14} \mathrm{C}$ was retained in their tissue at the end of the gut-fate experiment. This result, compared to a measured ${ }^{14} \mathrm{C}$-DEHP absorption efficiency of $24 \%$ ( $R$. Hansen unpubl. data) using a ${ }^{14} \mathrm{C}$-DEHP : ${ }^{51} \mathrm{Cr}$ duallabelling technique lasting $6 \mathrm{~h}$, suggests that worms are able to rapidly lower their DEHP body burden as has been previously shown for polycyclic aromatic hydrocarbons (PAH) (Lee \& Singer 1980, Forbes et al. 1996). In addition, the low ${ }^{14} \mathrm{C}$-body burden in the gutfate experiment was similar to the ${ }^{14} \mathrm{C}$-body burden measured in worm tissue from the microcosm experiment. However, worms in the microcosm experiment may just have avoided the contaminant due to a combination of their feeding mode and the sediment pulselabelling technique. It is possible that they altered their feeding mode in order to avoid the contaminant. The pre-exposed worms in the gut-fate experiment had a significantly higher $k_{\text {p Doc }}$ value compared to the control worms. Given the conditions of the present study, it is not possible to establish the physiological mechanisms responsible for the worms ability to initially excrete $\mathrm{DO}^{14} \mathrm{C}$ more rapidly when pre-exposed.

\section{CONCLUSIONS}

This study demonstrated that increasing densities of the deposit-feeding polychaete Capitella sp. I enhanced microbial ${ }^{14} \mathrm{C}$-DEHP mineralization. At present the mechanism is unknown but may be related to bioturbation or the action of gut microbes acting on solubilized contaminant which is retained relative to particulate matter and builds up within the gut lumen. The worms contribution to the ${ }^{14} \mathrm{CO}_{2}$ release per day due to gut passage in the microcosm study was maximally estimated to be $19 \%$ for the worm densities used in this study. The worms were able to excrete more than $99 \%$ of ${ }^{14} \mathrm{C}$-DEHP ingested during a $1 \mathrm{~h}$ ingestion period. Less than $1 \%$ was respired, $10 \%$ was excreted as $\mathrm{DO}^{14} \mathrm{C}$ and $89 \%$ as $\mathrm{PO}^{14} \mathrm{C}$. Less than $1 \%$ was retained in worm tissue.

Acknowledgements. We are grateful to Gary Banta, Anders Giessing and Liv Kure for critical comments on the manuscript. Jørgen Vikelsøe made the sediment background DEHP 
concentration measurements and Peter Kofoed assisted with $\mathrm{C}: \mathrm{N}$ analysis. This study was supported by grants to R. H. from the The Danish Plastics Federation and the private fund of Director J. P. Espersen and his wife, Mrs Dagny Espersen.

\section{LITERATURE CITED}

Adams WJ, Biddinger GR, Robillard KA, Gorsuch JW (1995) A summary of the acute toxicity of 14 phthalate esters to representative aquatic organisms. Environ Toxicol Chem 14 (9): $1569-1574$

Aller RC (1994) Bioturbation and remineralization of sedimentary organic matter: effects of redox oscillation. Chem Geol 114:331-345

Al-Omran LA, Preston MR (1987) The interactions of phthalate esters with suspended particulate material in fresh and marine waters. Environ Pollut 46:177-186

Bauer JE, Kerr RP, Bautista MF, Decker CJ, Capone DG (1988) Stimulation of microbial activities and polycyclic aromatic hydrocarbon degradation in marine sediments inhabited by Capitella capitata. Mar Environ Res 25:63-84

Berner RA (1980) Early diagenesis: a theoretical approach. Princeton University Press, Princeton, NJ

Boudreau BP (1998) Mean mixed depth of sediments: the wherefore and the why. Limnol Oceanogr 43:524-526

Brock TD (1979) The poisoned control in biogeochemical investigations. Strategies of microbial life in extreme environments. Berlin Dahlem Conferenzen

Cammen LM (1989) The relationship between ingestion rate of deposit feeders and sediment nutritional value. In: Lopez G, Taghon G, Levinton J (eds) Ecology of marine deposit feeders. Springer Verlag, New York, p 201-222

Crank J (1.975) Methods of solution when the diffusion coefficient is constant. In: the mathematics of diffusion. Clarendon, Oxford, p 11-27

Driscoll SBK, McElroy AE (1996) Bioaccumulation and metabolism of benzo[a]pyrene in three species of polychaete worms. Environ Toxicol Chem 15:1401-1410

Forbes TL (1989) The importance of size-dependent physiological processes in the ecology of the deposit-feeding polychaete Capitella species I. PhD dissertation, Marine Sciences Research Center, State University of New York at Stony Brook

Forbes TL (in press) Understanding small-scale processes controlling the bioavailability of organic contaminants to deposit-feeding benthos. In: Gray JS, Ambrose W (eds) Biogeochemical cycling in marine sediments. Kluwer Academic Publishing, Dordrecht

Forbes TL, Lopez GR (1989) Determination of critical periods in ontogenetic trajectories. Funct Ecol 3:625-632

Forbes TL, Forbes VE, Giessing A, Hansen R, Kure LK (1998) Relative role of pore water versus ingested sediment in bioavailability of organic contaminants in marine sediments. Environ Toxicol Chem 17:2453-2462

Forbes VE, Depledge MH (1992) Cadmium effects on the carbon. and energy balance of mudsnails. Mar Biol 113:263-269

Forbes VE, Forbes TL, Holmer M (1996) Inducible metabolism of fluoranthene by the opportunistic polychaete Capitella sp. I. Mar Ecol Prog Ser 132:63-70

Gardner WS, Lee RF, Tenore KR, Smith LW (1979) Degradation of selected polycyclic aromatic hydrocarbons in coastal sediments: importance of microbes and polychaete worms. Water Air Soil Pollut 11:339-347

Gibbons JA, Alexander M (1989) Microbial degradation of sparingly soluble organic chemicals: phthalate esters. Environ Toxicol Chem 8:283-291
Grassle JF, Grassle JP (1974) Opportunistic life histories and genetic systems in marine benthic polychaetes. J Mar Res $32: 253-283$

Grassle JP. Grassle JF (1976) Sibling species in the marine pollution indicator Capitella (polychaeta). Science 192: $567-569$

Gray JS (1981) The ecology of marine sediments. Cambridge University Press, Cambridge

Hedges JI, Stern JH (1984) Carbon and nitrogen determinations of carbonate-containing solids. Limnol Oceanogr 29 $657-663$

Holmer M, Forbes VE, Forbes TL (1996) Impact of the poly. chaete Capitella sp. I on microbial activity in an organicrich marine sediment contaminated with the polycyclic aromatic hydrocarbon fluoranthene. Mar Biol 128 $679-688$

Jobling S. Reynolds $T$, White $R$, Parker MG, Sumpter JP (1995) A variety of environmentally persistent chemicals, including some phthalate plasticizers, are weakly estrogenic. Environ Health Perspect 103:582-587

Kristensen E (1988) Benthic fauna and biogeochemical processes in marine sediments: microbial activities and fluxes. In: Blackburn TH, Sørensen J (eds) Nitrogen cycling in coastal environments. John Wiley \& Sons Ltd, London, p 275-295

Kristensen E. Blackburn TH (1987) The fate of organic carbon and nitrogen in experimental marine sediment systems influence of bioturbation and anoxia. J Mar Res 45 231-257

Kristensen E, Andersen FØ, Blackburn TH (1992) Effects of benthic macrofauna and temperature on degradation of macroalgal detritus: the fate of organic carbon. Limnol Oceanogr 37(7):1404-1419

Kure LK, Forbes TL (1997) Impact of bioturbation by Arenicola marina on the fate of particle-bound fluoranthene. Mar Ecol Prog Ser 156:157-166

Lee RF, Singer SC (1980) Detoxifying enzymes system in marine polychaetes: increases in activity after exposure to aromatic hydrocarbons. Rapp P-V Reun Cons Int Explor Mer 179:29-32

Lee RF, Hinga $K_{1}$ Almquist G (1982) Fate of radiolabeled polycyclic aromatic hydrocarbons and pentachlorophenol in enclosed marine ecosystem. In: Grice GD, Reeve MR (eds) Marine mesocosms-biological and chemical research in experimental ecosystems. Springer Verlag, New York, p $123-135$

Lopez G (1989) Radiotracer methods for determining utilization of sedimentary organic matter by deposit feeders. In: Lopez G, Taghon G, Levinton J (eds) Ecology of marine deposit feeders. Springer Verlag, New York, p 149-170

Madsen SD, Forbes TL, Forbes VE (1997) Particle-mixing by the polychaete Capitella species 1: coupling fate and effect of a particle-bound organic contaminant (fluoranthene) in a marine sediment. Mar Ecol Prog Ser 147:129-142

Mayer LM, Chen Z, Findlay RH, Fang J, Samson S, Self RFL, Jumars PA, Quetel C, Donard OFX (1996) Bioavailability of sedimentary contaminants subject to deposit-feeder digestion. Environ Sci Technol 30:2641-2645

McElroy AE, Farrington JW, Teal JM (1990) Influence of mode of exposure and the presence of a tubiculous polychaete on the fate of benz[a]anthracene in the benthos. Environ Sci Technol 24(11):1648-1655

Nozawa T, Maruyama Y (1988) Anaerobic metabolism of phthalate and other aromatic compounds by a nitrifying bacterium. J Bacteriol 170:5778-5784

Rhoads DC (1974) Organism-sediment relations on the muddy sea floor. Oceanogr Mar Biol Annu Rev 12:263-300 
Selck H, Decho AW, Forbes VE (in press) Effects of chronic metal exposure and sediment organic matter on digestive absorption efficiency of cadmium by the deposit-feeding polychaete Capitella species I. Env Toxicol Chem

Skoog DA, West DM, Holler FJ (1992) Errors in chemical analysis. In: Fundamentals of analytical chemistry. Saunders HBJ, New York, p 6-33

Taghon GL (1989) Modeling deposit feeding. In: Lopez G, Taghon G, Levinton $J$ (eds) Ecology of marine deposit feeders. Springer Verlag, New York, p 223-246

Editorial responsibility: Otto Kinne (Editor),

Oldendorf/Luhe, Germany
Wheatcroft RA, Jumars PA, Smith CR, Nowell ARM (1990) A mechanistic view of the particulate biodiffusion coefficient: step length, rest periods and transport directions. $J$ Mar Res 48:177-207

WHO (1992) Environmental health criteria 131:diethylhexyl phthalate. World Health Organization, Geneva

Williams MD, Adams WJ, Parkerton TF, Biddinger GR, Robillard KA (1995) Sediment sorption coefficient measurement for four phthalate esters: experimental results and model theory. Environ Toxicol Chem 14 (9):1477-1486

Submitted: January 5, 1998; Accepted: December 23, 1998 Proofs received from author(s): May 5, 1999 